\title{
ウルシの未成熟胚を用いた組織培養による 植物体再生に関する研究*1
}

\author{
塚田健太郎*2,3, 山岸祐介*4, 鍋嶋絵里*5, 保坂路人*2, 岡田健汰*2, \\ Md Hasnat Rahman*2,6，半 智史*2，田端雅進*7，船田 良*2 \\ Study of Plant Regeneration by Tissue Culture \\ from Immature Embryos of the Lacquer Tree, \\ Toxicodendron vernicifluum*1
}

\author{
Kentaro Tsukada*2,3, Yusuke Yamagishi*4, Eri NABeshima*5, \\ Michito Hosaka*2, Kenta OKadA*2, Md Hasnat Rahman*2,6, \\ Satoshi NAKABA*2, Masanobu TABATA*7 and Ryo FunAdA*2
}

\begin{abstract}
Resin and sap of lacquer trees (Toxicodendron vernicifluum) are called "Urushi". Urushi has been used for paints or adhesives since the Jomon period in Japan. Since it is prospective that demand for domestic Urushi for preservation of cultural property will increase, the mass production of seedlings of T. vernicifluum of high quality is important. We initially cultured immature zygotic embryos from immature fruits on Woody Plant Medium (WPM) containing 2,4-dichlorophenoxyacetic acid (2,4-D), $\alpha$ -naphthaleneacetic acid (NAA) or indole-3-acetic acid (IAA) as an auxin supplemented with polyvinylpyrrolidone (PVP). Somatic embryos were induced directly from immature zygotic embryos and secondary somatic embryos were induced from somatic embryos. Some secondary somatic embryos formed roots and hypocotyls. Finally, we transferred the secondary somatic embryo-derived plantlets to soil in pots and the plantlets continued to grow. Thus, we developed a tissue culture system for plant regeneration for the propagation of $T$. vernicifluum.
\end{abstract}

Keywords: immature zygotic embryos, polyvinylpyrrolidone, somatic embryogenesis, Toxicodendron vernicifluum, Urushi

*1 Received November 28, 2018; accepted March 4, 2019. 本研究の一部は第66回日本木材学会大会（2016年 3 月, 名古屋), 第67回日本木材学会大会 (2017年 3 月, 福岡) および第68回日本木材学会大会（2018年 3 月, 京都) で発 表した。

*2 東京農工大学大学院農学研究院 Faculty of Agriculture, Tokyo University of Agriculture and Technology, Fuchu 183-8509, Japan

*3 山梨県富士 ·東部林務環境事務所 Fuji-Tobu Branch Office for Forestry and Environment, Tsuru 402-0054, Japan

*4 北海道大学大学院農学研究院 Research Faculty of Agriculture, Hokkaido University, Sapporo 060-8589, Japan

*5 愛媛大学大学院農学研究科 Faculty of Agriculture, Ehime University, Matsuyama 790-8566, Japan

*6 東京農工大学大学院グローバルイノベーション研究院 Institute of Global Innovation Research, Tokyo University of Agriculture and Technology, Fuchu 183-8538, Japan

*7 森林総合研究所東北支所 Forestry and Forest Products Research Institute, Tohoku Research Center, Morioka 020-0123, Japan

Corresponding author : R. Funada(funada@cc.tuat.ac.jp) 
ウルシ（Toxicodendron vernicifluum）の樹脂を含む樹液は「漆」と呼ばれ，縄文時代から塗料・接着用 途に利用されている。現在，文化財修復用途として国産漆の需要の増加が見込まれているため，良質な苗木 の大量生産が重要である。そこで本研究では, ウルシの植物体再生系の確立を目標として, ウルシの未成熟 肧をオーキシンとして2,4-ジクロロフェノキシ酢酸（2,4-D)， $\alpha$-ナフタレン酢酸（NAA）またはインドール3-酢酸（IAA）とポリビニルピロリドン (PVP) を添加したWoody Plant Medium（WPM）培地に植えつけ た。その結果, 不定胚の形成が認められ，さらに不定胚から二次不定胚の形成が認められた。形成された二 次不定胚の一部は, 明条件下において植物体に成長し, 組織培養を用いたウルシの未成熟胚からの植物体再 生に成功した。

\section{1. 緒言}

ウルシ（Toxicodendron vernicifluum）は，ウル シ科ウルシ属の樹種であり, 樹脂を含む樹液は「漆」 と呼ばれ, 縄文時代から塗料や接着剂などに利用さ れてきた ${ }^{1)}$ 。しかしながら，現在漆の国内自給率は 約 $3 \%$ となっている2)。この状況に対し，文化庁は 平成30年度より，国宝や重要文化財の修理には原則 として100\%国産漆を使う方針を示しており ${ }^{3)}$ ，今 後, 国産漆の需要の増加が見込まれている。しかし ながら，ウルシは個体によって漆生産量に差がある ことが知られておりり ${ }^{4,5)}$, 漆を大量に生成できる苗 木の生産が重要である。

ウルシの従来の増殖法には, 主に実生苗と分根苗 による 2 つの育成法がある ${ }^{6)}$ 。実生苗による育成法 は一度に大量の苗を生産可能だが, 同一形質の苗を 生産することはできない。また，発芽には種子の口 ウ成分を除去するための脱口ウ処理を行う必要があ る。一方, 分根苗による育成法は, 母樹と同じ形質 をもった苗を生産可能であるが，一本の母樹から大 量の苗木を生産することは困難である ${ }^{6)}$ 。

植物組織培養技術を用いた植物体再生系は, 同一 形質をもった苗木を大量に生産可能である。ウルシ の組織培養に関しては, 成熟胚を Murashige and Skoog（MS）培地にオーキシンの2,4-ジクロロフェ ノキシ酢酸（2,4-D）を添加した条件で培養し，さ らに2,4-D 無添加の MS 液体培地に移植した結果, 不定根が誘導され, 不定根からウルシオールが検出 された報告7) がある。また, ウルシと同じウルシ属 のハゼノキ (Toxicodendron succedaneum) におい ては, 無菌発芽苗の肧軸からシュートを形成し, 植 物体を得た報告8 ${ }^{8}$ がある。しかしながら, 植物組織 培養技術によるウルシの植物体再生に成功した報告 はない。そこで本研究では, 植物組織培養技術を用 いたウルシの未成熟肧からの植物体再生系の確立を 目的として実験を行った。

\section{2. 実験方法}

\section{1. 材料}

茨城県常陸大宮市に生育するウルシから果実を採 取した（Fig. 1A，B）。果実の採取は，2016年におい ては, 5 年生で樹高 $4.3 \mathrm{~m}$, 胸高直径 $8.5 \mathrm{~cm}$ の母樹 1 個体から 6 月 21 日, 7 月 6 日, 7 月 19 日, 8 月 2 日に行い, 2017 年においては, 7 年生で樹高 $6.3 \mathrm{~m}$, 胸高直径 $8.6 \mathrm{~cm}$ の母樹 1 個体から 6 月 23 日, 7 月 10 日，7月25日，8月 8日に行った。ウルシの開花日 は, 2016年が 5 月29日頃で, 2017年が 6 月 6 日頃で あった。

\section{2. 滅菌}

毎年, 採取 2 回目までの果実はそのまま, 採取 3 回目以降の果実は外果皮㧍よび中果皮を取り除いた 後, 中性洗剂を用いて洗浄した (Fig. 1C)。30分間 流水で洗浄し, $70 \%$ エタノールに 3 分間浸漬した後, 界面活性剂の TWEEN20 2, 3 滴添加した 3 \%次 亜塩素酸ナトリウム水溶液中に 20 分間浸漬し滅菌を 行った。滅菌後, クリーンベンチ内で果実または種 子をメスで切断して未成熟胚を取り出し, $90 \mathrm{~mm}$ シャーレに入った誘導培地上に植えつけた。

\section{3. 不定胚の誘導}

誘導培地は, ウルシ属であるハゼノキの組織培養 の報告8) を基に, 基本培地としてWoody Plant Medium (WPM) 培地 ${ }^{9)}$ を用い, スクロース $20 \mathrm{~g} / \mathrm{L}$, グルタミンを $500 \mathrm{mg} / \mathrm{L}$ ，カゼインを $1 \mathrm{~g} / \mathrm{L}$ の割合 で添加した。 $\mathrm{pH}$ は5.8に調整し, 固化剂としてゲラ ンガム $3 \mathrm{~g} / \mathrm{L}$ を用いた。グルタミン，カゼインおよ び後述するインドール-3-酢酸（IAA）はフィル夕 一滅菌し, オートクレーブ後の培地に添加した。

2016年は，オーキシンとして2,4-D を $1 \mu \mathrm{M} ， \alpha$ ナフタレン酢酸（NAA）またはIAAを 1 また は $5 \mu \mathrm{M}$ 添加するという 5 条件と, 植物ホルモン無 添加（HF）の 1 条件を合わせた 6 条件を設定した。 また，ポリビニルピロリドン (PVP) $1 \mathrm{~g} / \mathrm{L}$ を添加 または無添加とする 2 条件を設定した。

2017年は, 2016年の実験結果を参考にして, オー キシンとしてNAAを $1 \mu \mathrm{M}$ または IAA $5 \mu \mathrm{M}$ 添 

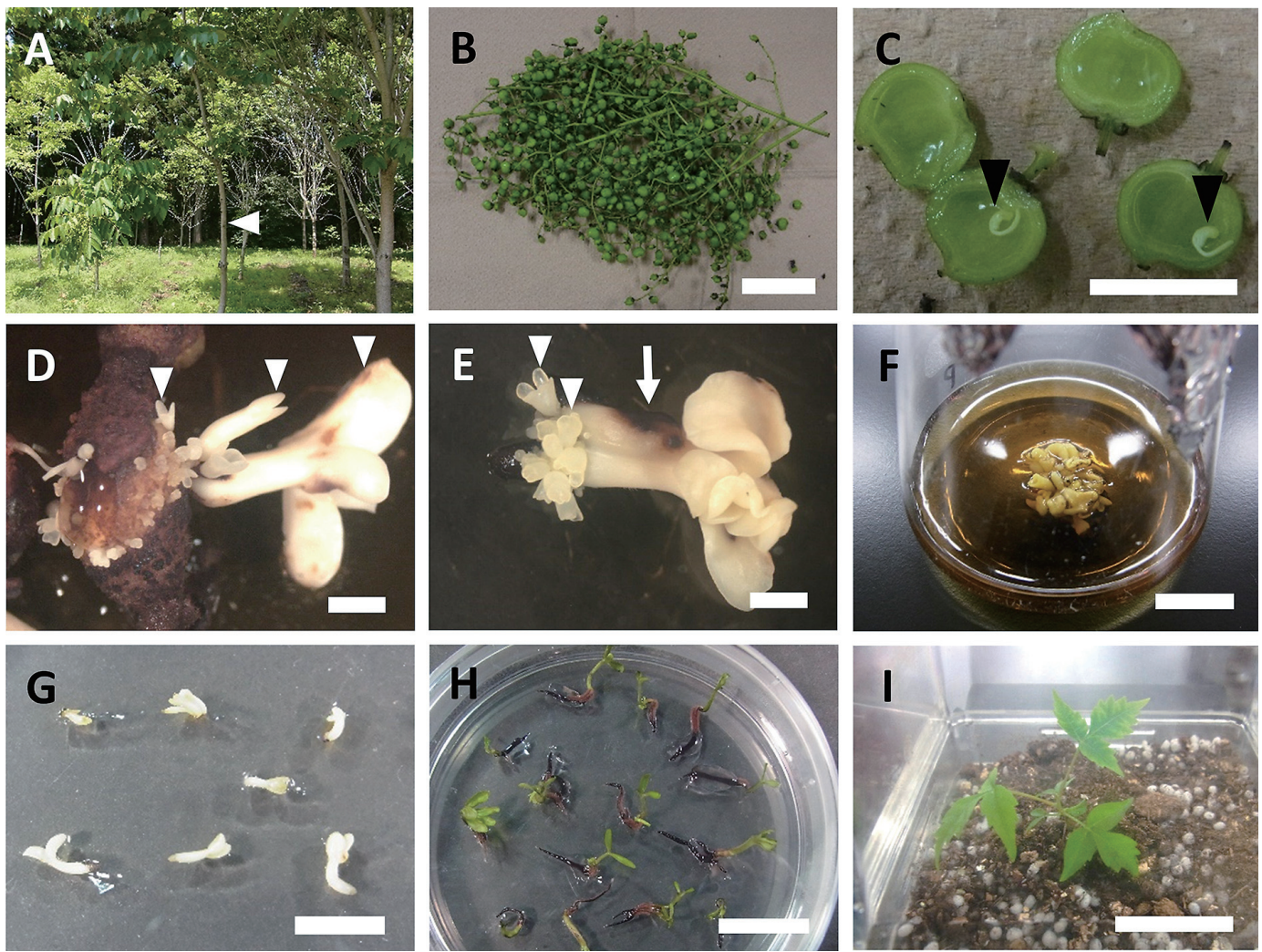

Fig. 1. Plant regeneration from immature zygotic embryos of Toxicodendron vernicifluum.

Legend: A : A tree (an arrowhead) from which we collected fruits on 23 June 2017.

B : Fruits collected on 23 June 2017. Scale bar $=4 \mathrm{~cm}$.

C: An immature embryo (arrowheads) from a fruit collected on 23 June 2017. Scale bar $=1 \mathrm{~cm}$.

D : Somatic embryos (arrowheads) induced on WPM medium containing $1 \mathrm{~g} / \mathrm{L} \mathrm{PVP}$ and $1 \mu \mathrm{M}$ IAA. Scale bar $=2 \mathrm{~mm}$

E: Secondary somatic embryos (arrowheads) induced from a somatic embryo (an arrow). Scale bar $=2 \mathrm{~mm}$.

F : Somatic embryos developed on liquid WPM medium. Scale bar $=2 \mathrm{~cm}$.

$\mathrm{G}$ : Secondary somatic embryos separated from a somatic embryo. Scale bar $=1 \mathrm{~cm}$.

$\mathrm{H}$ : Plantlets with roots and cotyledons derived from secondary somatic embryos. Scale bar $=2 \mathrm{~cm}$.

I: A plantlet 17 days after the transfer to soil in the pot. Scale bar $=2 \mathrm{~cm}$.

加するという 2 条件と, HF の 1 条件を合わせた 3 条件を設定した。また, PVPをそれぞれ0.5, 1.0, $3.0 \mathrm{~g} / \mathrm{L}$ 添加または無添加とする 4 条件を設定した。 培養は $25{ }^{\circ} \mathrm{C}$ 暗条件下で行い, 約 1 ヶ月ごとに同組成 の培地で継代を行った。

誘導開始から2016年の実験では 9 ケ月後，2017年 の実験で 7 ケ月後の時点において, 植え付けを行っ た未成熟胚のうち，不定胚の形成が認められた未成 熟胚の数をカウントした。

\section{4. 不定胚の増殖}

固体培地上で増殖が認められない不定胚について は, 不定肧の増殖のため液体培地に移した。液体培
地は，誘導培地と同組成で，植物ホルモン，PVP およびゲランガムを無添加とした培地とした。約 3 週間, $70 \mathrm{rpm}$ で回旋培養（MMS-3010, 東京理化 器械)を行った。

\section{5. 不定胚の成熟}

形成された不定胚は, 発芽㧍よび発根を促すため, 不定胚成熟培地（植物ホルモンを無添加とした WPM 培地) に移した。発芽が認められた不定肧は, $25{ }^{\circ} \mathrm{C}$ ，18時間日長で培養を行った。本葉が発生した 植物体は, 植物組織培養用プラントポット（三商） に入った土壤（バーミキュライト：パーライト：ピ 一トモス $=1: 1: 1$ または $2: 2: 1)$ に移植し, ハイ 
ポネックスを滅菌水で約2000倍に薄めた溶液を与え た。その後, 土壤の表面が乾くごとに滅菌水を与え た。

\section{6. 二次不定胚の形成}

2016年の実験において誘導された不定胚の内，二 次不定胚の形成が活発な 1 系統を用いて, PVP の 濃度が不定肧の増殖に与える影響を観察した。誘導 培地と同組成で PVPをそれぞれ $0,1,3 \mathrm{~g} / \mathrm{L}$ の濃度 で添加した植物ホルモン無添加の培地に初期の子葉 肧を移し，35日間培養を行った後，形成された二次 不定胚の数を記録した。

\section{7. 統計解析}

二次不定肧形成に対する培地条件の影響につい て, 二次不定胚形成を被説明変数とし, 培地条件を 説明変数とする線形モデルを組み立て, 統計解析を 行った。培地条件間の比較は, モデル選択によって 行い, 当てはまりの良さの基準として赤池情報量基 準（AIC）を用いた。確率分布としてポアソン分布 を仮定し，PVP 濃度を連続変数とした。すべての 統計解析は R（version 3.2.3 $)^{10)}$ を用いて行った。

\section{3. 結果および考察}

\section{1. 不定胚の誘導における果実の採取時期の影響}

2016年の実験では，植えつけた未成熟胚900個体 中，50個体から不定肧が誘導された。不定胚は， 1 個体から複数の誘導が多くみられた（Fig. 1D）。 2017年の実験では, 植えつけた未成熟胚825個体中, 33個体から不定胚が誘導された。なお，2016年 7 月 19日と2017年 8 月 8 日採取の果実から摘出した未成 熟胚は, 植え付け後に全て雑菌污染により枯死した。

2016年に扔ける，果実の採取日ごとの未成熟胚か らの不定胚誘導数扔よび誘導率を Table 1 に示し た。果実の採取時期の違いの有意な影響が認められ, 7 月 6 日採取の果実の未成熟胚は, 異なる 2 度の時 期に採取された果実の未成熟肧と比べ不定肧の誘導 率が高く $12 \%$ と最大になった。2016年のウルシの 開花日は 5 月 29 日ごろであったため, 7 月 6 日は開 花後 5 - 6 週にあたる。

2017年に㧍ける，果実の採取日ごとの，未成熟胚 からの不定胚誘導数拈よび誘導率を Table 2 に示 した。2017年に抒いては，果実の採取時期に未成熟 胚からの不定胚誘導率への有意な影響は認められな かった。不定胚誘導率は, 2 回目の採取である 7 月 10日で $4 \%$ と最大になった。2017年のウルシの開花 日は 6 月 6 日ごろであったため, 7 月10日は開花後 4 - 5 週にあたる。

2016年の結果から，ウルシの不定胚誘導には，開
Table 1. Induction of somatic embryos from immature zygotic embryos from fruits sampled on different dates in 2016.

\begin{tabular}{cccc}
\hline \hline $\begin{array}{c}\text { Sampling } \\
\text { date. }\end{array}$ & $\begin{array}{c}\text { No. of } \\
\text { explant }\end{array}$ & $\begin{array}{c}\text { No. of } \\
\text { somatic embryo }\end{array}$ & $\begin{array}{c}\text { Induction ratio } \\
(\%)\end{array}$ \\
\hline 21 June & 300 & 9 & 3 \\
6 July & 300 & 35 & 12 \\
2 August & 300 & 6 & 2 \\
\hline
\end{tabular}

Notes: Induction ratios were calculated by no. of explants forming somatic embryos / no. of explants $\times 100$.

Table 2. Induction of somatic embryos from immature zygotic embryos from fruits sampled on different dates in 2017.

\begin{tabular}{cccc}
\hline \hline $\begin{array}{c}\text { Sampling } \\
\text { date. }\end{array}$ & $\begin{array}{c}\text { No. of } \\
\text { explant }\end{array}$ & $\begin{array}{c}\text { No. of } \\
\text { somatic embryo }\end{array}$ & $\begin{array}{c}\text { Induction ratio } \\
(\%)\end{array}$ \\
\hline 23 June & 300 & 10 & 3 \\
10 July & 300 & 16 & 5 \\
25 July & 225 & 7 & 3 \\
\hline
\end{tabular}

Notes: Induction ratios were calculated by no. of explants forming somatic embryos / no. of explants $\times 100$.

花後 $5-6$ 週頃の胚の発達段階が適している可能性 が示唆された。植え付け年の違いによって, 開花後 の期間がほぼ等しい未成熟胚からの不定胚の誘導数 が大きく異なった要因として, 採取した母樹が異な ることによる肧の遺伝的性質の違いや, 積算温度な どの違いによって脹の発達速度に差が生じていた可 能性が考えられる。

\section{2. 不定胚の誘導における植物ホルモンおよび添 加物質の影響}

2016年の実験における，培地条件ごとの不定肧誘 導数および誘導率を Fig. 2 に示した。PVP $1 \mathrm{~g} / \mathrm{L}$ と NAA $1 \mu \mathrm{M}$ を添加した条件から誘導された不定胚 の内 2 系統と PVP $1 \mathrm{~g} / \mathrm{L}$ と IAA $5 \mu \mathrm{M}$ を添加した 条件から誘導された不定胚の内 1 系統は, 植物ホル モンを無添加とした培地において, 活発な二次不定 肧形成を繰り返した（Fig. 1E)。不定胚の増殖性と いう観点から，2016年の実験では，この 2 条件がウ ルシの不定肧誘導に適していたと考えられる。

2017年の実験における，培地条件ごとの不定肧誘 導数および誘導率を Fig. 3 に示した。HF 条件, IAA $5 \mu \mathrm{M}$ 添加条件, NAA $1 \mu \mathrm{M}$ 添加条件の順に 不定胚誘導率が高い值を示した。また，PVPの添 加濃度が高いほど, 不定胚誘導率が高くなった。

以上の結果から, 誘導培地への PVP および植物 ホルモンの添加にウルシの不定肧誘導への影響が認 められたものの, 植え付け年や両者の条件の組み合 


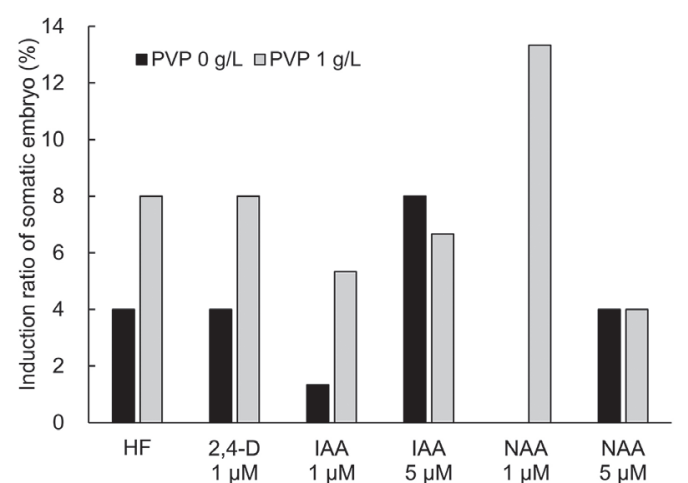

Fig. 2. Induction of somatic embryos from immature zygotic embryos in 2016.

Notes: Induction ratios were calculated by no. of explants forming somatic embryos / no. of explants $\times 100$, PVP : polyvinylpyrrolidone, HF : hormone free, 2,4-D : 2,4-dichlorophenoxyacetic acid, NAA : $\alpha$-naphthaleneacetic acid, IAA : indole-3-acetic acid

わせによって影響が異なっており，一定した効果は 認められなかった。

\section{3. 二次不定胚の誘導における PVP の影響}

異なる PVP 濃度における供試数, 二次不定胚の 形成数, および 1 供試体当たりの二次不定胚形成数 を Table 3 に示した。培地のPVP濃度の違いにより， 二次不定胚の形成数への有意な影響が認められた。 PVPを無添加及び $1 \mathrm{~g} / \mathrm{L}$ 添加の培地に対し, PVP を $3 \mathrm{~g} / \mathrm{L}$ 添加した培地では有意に二次不定肧の形成 数が多く，1つの不定胚から 35 日間で平均4.2個の 二次不定肧が形成された。この結果から, PVPの 添加は, ウルシの二次不定胚形成を促進すると考元 られる。

PVPは,フェノール類を吸着するため, 褐変を 減らす目的に用いられる高分子化合物である ${ }^{11)}$ 。ウ ルシ科のカシュー (Anacardium occidentale) にお いても，培地中に $0.1 \% の P V P$ を添加することによ

Table 3. Effects of PVP concentration on the number of secondary somatic embryos induced from somatic embryos.

\begin{tabular}{cccc}
\hline \hline $\begin{array}{c}\text { PVP } \\
(\mathrm{g} / \mathrm{L})\end{array}$ & $\begin{array}{c}\text { No. of } \\
\text { SE }\end{array}$ & $\begin{array}{c}\text { No. of } \\
\text { SSE }\end{array}$ & $\begin{array}{c}\text { SSE } \\
\text { /SE }\end{array}$ \\
\hline 0 & 33 & 94 & $2.8^{\mathrm{b}}$ \\
1 & 34 & 109 & $3.2^{\mathrm{b}}$ \\
3 & 34 & 144 & $4.2^{\mathrm{a}}$ \\
\hline
\end{tabular}

Notes: Different letters indicate significant differences among means at $p<0.01$, PVP : polyvinylpyrro lidone; SE : somatic embryo; SSE: secondary somatic embryo.

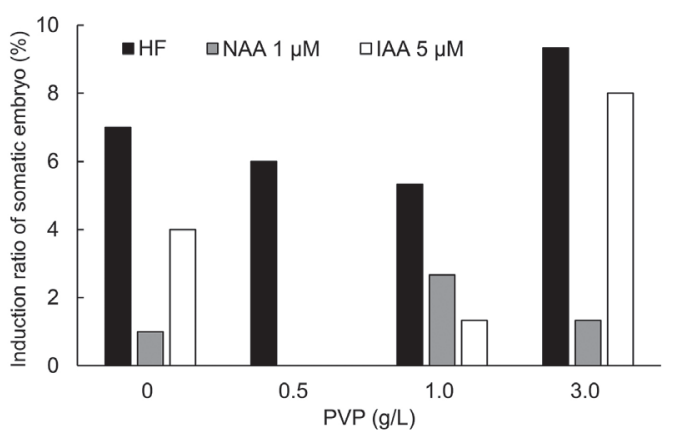

Fig. 3. Induction of somatic embryos from immature zygotic embryos using PVP and auxins in 2017.

Notes: Induction ratios were calculated by no. of explants forming somatic embryos / no. of explants $\times 100$, PVP: polyvinylpyrrolidone, HF : hormone free, NAA : $\alpha$-naphthaleneacetic acid, IAA : indole-3-acetic acid

ってフェノール類の渗出が減少したという報告があ る ${ }^{12)}$ 。本研究においては, PVPによって不定胚の 形成を阻害するフェノール類が吸着されたことで, ウルシの二次不定肧形成が促進された可能性がある。

\section{4. 不定胚の増殖}

固体培地上で二次不定胚形成や成長が認められな い不定肧について, 同組成の液体培地に移し回旋培 養を行ったところ, 不定肧の発達が認められた (Fig. $1 \mathrm{~F})$ 。これは, 液体培養によって不定肧全体 に培地が接していたためであると考えられる。液体 培地には著しい褐変が観察されたが, 不定肧が枯死 することはなかった。液体培養で発達した不定肧を 同組成の固体培地に移したところ, 肧軸の伸長や展 葉といった発達が進むことはなかったが, 活発な二 次不定肧形成が認められた。液体培地による培養は, 不定胚の増殖に有効である可能性が示唆された。

\section{5. 不定胚の成熟}

2016年の実験において，1 g/L の PVP および $1 \mu \mathrm{M}$ の IAA を添加した培地でウルシ未成熟胚か ら誘導された不定胚を不定肧成熟培地に移したが, 肧軸の伸長や展葉といった発達が進む不定胚は認め られなかった。一方，3.1において活発な二次不定 肧形成を繰り返した系統に扔いて, 形成された二次 不定肧を不定胚から取り外し, 不定胚成熟培地に移 したところ（Fig. 1G），一部の二次不定胚は植物体 にまで成長した (Fig. 1H)。本葉が 2 から 3 枚展開 した段階で植物体を土壤に移植したところ，25本中 20本の植物体が土壌においてさらに成長した (Fig. 1I)。本研究において, 組織培養技術を用いた ウルシの未成熟胚からの植物体再生に成功した。 


\section{4. 結 論}

本研究に打いて, ウルシの未成熟胚をWPM 培 地に植えつけた結果, 植えつけた肧から直接不定胚 が誘導された。誘導された不定肧の一部では, 活発 な二次不定胚形成が認められたため, ウルシの大量 増殖には二次不定肧を用いることが有効であると考 えられる。ウルシ科のマンゴー (Mangifera indica) に抢いては，未成熟胚の子葉部分から不定肧形成細 胞 (PEMs)のような細胞の形成が認められており, 細胞からの不定肧形成と植物体再生に成功してい る ${ }^{13)}$ 。また, 成熟した不定胚の肧軸から二次不定胚 の形成が報告されている。一方，カシュー $(A$. occidentale) においては, 種皮から直接不定肧が誘 導され，不定胚 1 つから 10 個以上の二次不定胚が形 成し, 植物体再生に成功している ${ }^{14)}$ 。このように, ウルシ科の組織培養を用いた植物体再生の中でも, マンゴーのようにPEMsを用いた大量増殖が有効 である場合と，カシューのように二次不定肧形成を 用いた大量増殖が有効である場合がある。本研究の ウルシでは, PEMsの形成が揌められなかったが, 活発な二次不定胚形成が認められたため, ウルシ科 の中ではカシューの組織培養に類似しているといえ る。

本研究の成果により, ウルシの未成熟胚からの組 織培養技術を用いた植物体再生に成功した。同じ遺 伝的形質を持つ苗木の大量生産が可能になったこと で, さらに得られた苗木の系統ごとの漆生産性の検 定と選抜の実施により, 高い漆生産性をもつウルシ の効率的な苗木生産が可能になる。

\section{謝辞}

本研究は，平成26 29年度科学研究費補助金（基 盤研究A）「漆生成メカニズムに基づく高品質漆の 開発; 研究代表者:田端 雅進」によって行われた。 ウルシ果実の試料採取にあたり, 奥久慈漆生産組合 長の神長正則氏にご協力を戴き，御礼申し上げる。

\section{文献}

1) Noshiro, S., Suzuki, M., Sasaki, Y.: Importance of Rhus verniciflua Stokes (lacquer tree) in prehistoric periods in Japan, deduced from identification of its fossil woods. Veg. Hist. Archaeobot. 16(5), 405-411 (2007).

2) 林野庁: 平成 28 年度 森林. 林業白書, 日本林 業協会, 東京, 2016, p.117.

3）文化庁「国宝・重要文化財（建造物）保存修
理における漆の使用方針について」平成 27 年 2 月24日付け26庁財第510号 (2015).

4）原田盛重：漆液収量に関する樹幹組織の定量 的研究. 日本林学会誌 24(4), 207-214 (1942).

5) Zhao, M., Liu, C., Zheng, G., Wei, S., Hu, Z: Comparative studies of bark structure, lacquer yield and urushiol content of cultivated Toxicodendron vernicifluum varieties. New Zeal. J. Bot. 51, 13-21 (2013).

6）田端雅進：植物としてのウルシ。“地域資源を いかす 生活工芸双書 漆 1 漆搔きと漆工 ウル 三利用”, 室瀬和美, 田端雅進監修, 農山漁村文 化協会, 東京, 2018, pp. 14-15.

7) 橋本 修, 南 享二 : ウルシノキの組織培養とウ ルシオールの形成（第 3 報）ウルシノキ不定 根によるウルシオールの形成. 木材学会誌 26 (1), 49-53 (1980).

8）戸田忠雄, 西村慶二, 山手廣太 : ハゼノキの組 織培養. 林木育種センター研究報告 13, 53-64 (1995).

9) Lloyd, G., McCown, B. : Commercially-feasible micropropagation of mountain laurel, Kalmia latifolia, by use of shoot-tip culture. Comb. Proc. Int. Plant Propagators' Soc. 30, 421-427 (1980).

10) R Core Team (2015). R: A language and environment for statistical computing. $\mathrm{R}$ Foundation for Statistical Computing, Vienna, Austria. https://www.R-project.org/. 2016年 1 月 4 日参照.

11) Loomis, W.D., Battaile, J.: Plant phenolic compounds and the isolation of plant enzymes. Phytochemistry 5, 423-438 (1966).

12) Thimmappaiah, Shirly R.A., Sadhana, P.H.: In vitro propagation of cashew from young trees. In Vitro Cell. Dev. Biol., Plant 38, 152 -156 (2002).

13) Xiao, J.N., Huang, X.L., Wu, Y.J., Li, X.J., Zhou, M.D., Engelmann, F.: Direct somatic embryogenesis induced from cotyledons of mango immature zygotic embryos. In Vitro Cell. Dev. Biol., Plant 40, 196-199 (2004).

14) Martin, K.P.: Plant regeneration through direct somatic embryogenesis on seed coat explants of cashew (Anacardium occidentale L.). Sci. Hortic. 98, 299-304 (2003). 